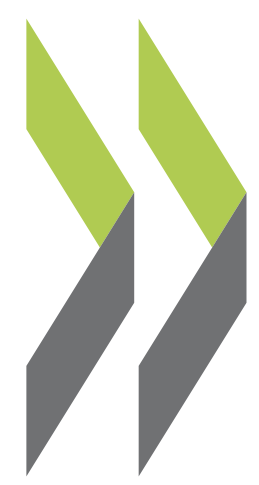

OECD Working Papers on International Investment 2017/02

The balance between investor protection and the right to regulate David Gaukrodger in investment treaties: A scoping paper 


\section{OECD WORKING PAPERS ON INTERNATIONAL INVESTMENT}

OECD Working Papers should not be reported as representing the official views of the OECD or of its member countries. The opinions expressed and arguments employed are those of the authors.

Working Papers describe preliminary results or research in progress by the author(s) and are published to stimulate discussion on a broad range of issues on which the OECD works. Comments on Working Papers are welcomed, and may be sent to investment@oecd.org or the Investment Division Directorate for Financial and Enterprise Affairs, OECD, 2 rue André-Pascal, 75775 Paris Cedex 16, France.

The international investment working paper series - including policies and trends and the broader implications of multinational enterprise - is designed to make available to a wide readership selected studies undertaken under the aegis of the OECD Investment Committee, by OECD staff, or by outside consultants working on OECD Investment Committee projects.

The papers are generally available only in their original language English or French with a summary in the other if available.

\section{OECD WORKING PAPERS ON INTERNATIONAL INVESTMENT are published on www.oecd.org/investment/working-papers.htm.}

This document and any map included herein are without prejudice to the status of or sovereignty over any territory, to the delimitation of international frontiers and boundaries and to the name of any territory, city or area.

\section{(C) OECD 2017}

You can copy, download or print OECD content for your own use, and you can include excerpts from OECD publications, databases and multimedia products in your own documents, presentations, blogs, websites and teaching materials, provided that suitable acknowledgment of OECD as source and copyright owner is given. All requests for commercial use and translation rights should be submitted to rights@oecd.org. 


\title{
The balance between investor protection and the right to regulate in investment treaties \\ A scoping paper
}

\author{
by
}

David Gaukrodger

\begin{abstract}
This scoping paper examines the balance between investor protection and the right to regulate in investment treaties and investment treaty policy. It notes the growing trend to analyse the impact of particular treaty rules rather than treaties as a whole. It also points to the importance of comparative analysis of balancing under other regimes. It then outlines issues in four areas: (i) the types of regulation potentially at issue in investment treaty claims by covered investors; (ii) the types and levels of investor protection; (iii) the degree of impact of treaties on regulation; and (iv) the processes and institutions that may be involved in balancing interests in investor protection and the right to regulate. While the paper recognises that dispute resolution institutions have a significant impact on the balance and the right to regulate, it focuses primarily on substantive issues in light of other ongoing work on dispute settlement.
\end{abstract}

Authorised for release by Pierre Poret, Director, OECD Directorate for Financial and Enterprise Affairs

JEL Classification: F02, F13, F21, F23, F53, F60, H11, H40, K4, K23, K29, K33

Keywords: investment treaties; bilateral investment treaties; investor protection; right to regulate; regulatory autonomy; policy space; regulatory chill; investment treaty policy; investor-state dispute settlement; ISDS; international arbitration; settlement; international economic law; balancing of interests; balancing of policy goals; investment arbitration; foreign investment; international investment; international investment law; international investment agreements. 


\section{Table of contents}

Executive summary

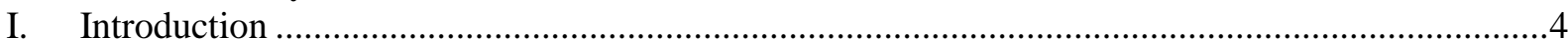

II. The balance between investor protection and the right to regulate is a central issue in current debates and policies concerning investment treaties .....................................................6

III. Policy analysis of investment treaties is increasingly focused on the impact of

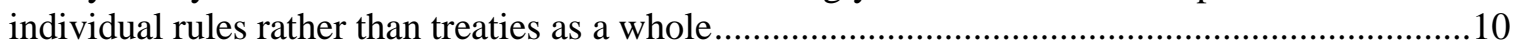

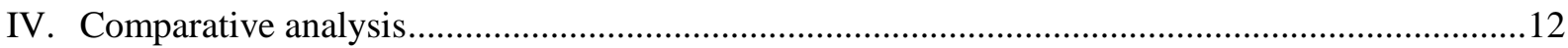

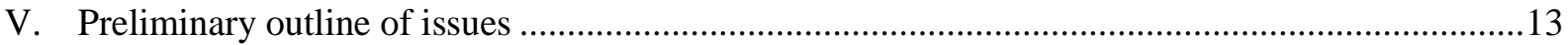

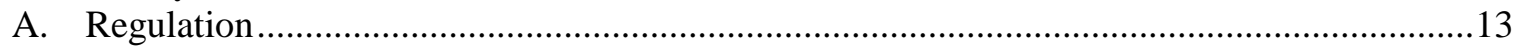

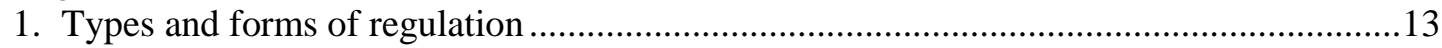

2. Regulation in different economic areas .......................................................................16

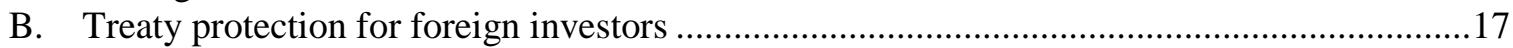

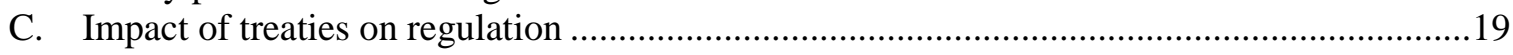

1. The impact of cases, damages liability and settlements ..................................................19

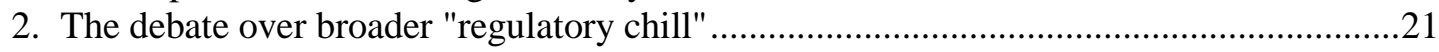

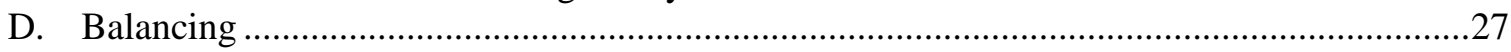

1 Economic analysis of investment treaty rules can provide useful theoretical insights and generate empirical questions for testing.................................................................27

2. Careful analysis of rules may allow for a reduced need for balancing of policy

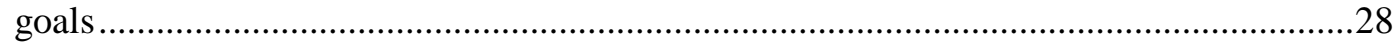

3. Governments can use a wide variety of techniques to adjust the balance in future treaties and related law, but addressing the many existing treaties is difficult .................29

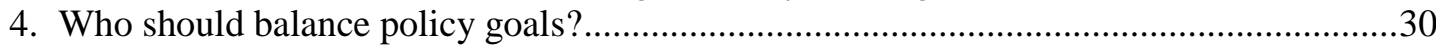

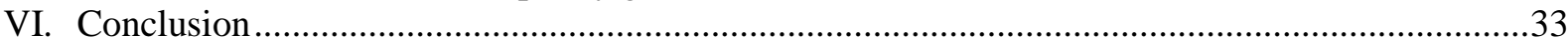




\section{Executive summary}

There is vigorous debate about the balance between investor protection and the right to regulate in the over 3000 existing investment treaties. This paper outlines issues in four areas: (i) the types of regulation potentially at issue in investment treaty claims by covered investors; (ii) the types and levels of investor protection; (iii) the degree of impact of treaties on regulation; and (iv) the processes and institutions that may be involved in balancing interests in investor protection and the right to regulate. While the paper recognises that dispute resolution institutions have a significant impact on the balance and the right to regulate, it focuses primarily on substantive issues in light of other ongoing work.

Although limitations have been introduced in some treaties, most investment treaties can apply to practically the full variety of national government action. Different sensitivities and issues are raised by the application of treaties to national legislation as opposed to challenges to the procedures employed in individual decisions. Governments are increasingly adopting special rules in treaties for particular policy areas (such as tax or financial services) or specific economic sectors, generally to provide additional protection to regulation in those areas.

Governments can and do expropriate investors or discriminate against them and it is important to provide investors with recourse against governments. Domestic legal systems provide investors with one option for protecting themselves. Investment treaty provisions can give substantial additional leverage to covered foreign investors in their dealings with host governments. Different levels of protection for different investors, however, may complicate the regulatory process. This can occur where a government has treaties with different investor protection provisions or where treaty protections exceed protections under domestic law. Some governments have sought to define model treaties with a well-defined and consistent level of exposure to covered investor claims, in some cases in a manner that aligns with substantive protections under their national law.

Evaluation of the impact of treaties on regulatory policy can address the degree of impact and whether the impact is good or bad from a policy perspective. The degree of treaty impact on regulatory policy will notably depend on whether relevant government actors are aware of the treaties and their provisions, the dissuasive power of treaties, and the applicable types of treaty rules. Damages remedies available under treaties may have different dissuasive power, for example, than the nonpecuniary remedies to which investors are generally limited under domestic law. ${ }^{1}$ Evaluation of positive and negative impacts would require detailed analysis and is deferred.

The balancing of interests in investment treaties can involve different processes and institutions. Executive and legislative bodies can both participate in the balancing process in investment treaty policy (as can different levels of government in federal-type systems). As public interest in treaties and their impact on regulation has grown, parliaments have become more active in influencing the balance. Development of a model treaty, while challenging, may help address concerns about one government binding a future and differently-oriented government to policy constraints. Questions can also arise about what role adjudicators should have, if any, in balancing policy goals. Courts generally lack the democratic legitimacy of parliaments and their role in balancing policy goals, if any, is often perceived as controversial; specificities of investor-state dispute settlement (ISDS) compared to courts raise additional issues. The paper notes the potential to reduce the scope for balancing by adjudicators through careful analysis and treaty drafting.

David Gaukrodger \& Kathryn Gordon, Investor-State Dispute Settlement: A scoping paper for the investment policy community, OECD Working Paper on International Investment 2012/03, Annex IV. 


\section{Introduction ${ }^{2}$}

The issue of the balance between investor protection and the right to regulate is a key issue both in the current public debate about investment treaties and for governments' treaty policy. Much of the current criticism of treaties focuses on their alleged impact on the right to regulate. In contrast, defenders of treaties contend that treaties protect covered investors from government misrule and can have a positive impact on the quality of government regulation. A wide range of governments are recognising the importance of the issue of balance while adopting varying policy responses.

For the FOI Roundtable, consideration of the balance between investor protection and the right to regulate involves discussion of the substantive law of investment treaties. ${ }^{3}$ It follows work primarily focused on the question of investor-state dispute settlement (ISDS) since 2011. While substantive law is largely a new area for the Roundtable, earlier work prepared for the OECD Investment Committee considered substantive law issues raised under various treaty provisions. ${ }^{4}$ Those papers are a valuable resource. At the same time, they also reveal the rapid development and evolution of certain protections notably as a result of arbitral decisions and reliance on arbitral precedent in ISDS. For example, the issue of legitimate expectations, which has grown to be a prominent component of some versions of the fair and equitable treatment (FET) clause, was not mentioned in the 2004 paper on FET. ${ }^{5}$

The subject is broad. It reaches across practically the full range of government regulatory activity. Many treaty provisions are at issue. It is accordingly useful to proceed by steps. This scoping paper has the modest goal of outlining the main concepts at issue, identifying some research and analysis of interest, and pointing towards some areas where the work and dialogue could focus. A companion

2 This paper does not necessarily reflect the views of the OECD or of the governments that participate in the Freedom of Investment (FOI) Roundtable, and it should not be construed as prejudging ongoing or future negotiations or disputes pertaining to international investment agreements. The following economies are invited to participate in the Roundtable: Argentina, Australia, Austria, Belgium, Brazil, Bulgaria, Canada, Chile, People's Republic of China, Colombia, Costa Rica, Czech Republic, Denmark, Egypt, Estonia, Finland, France, Germany, Greece, Hungary, Iceland, India, Indonesia, Ireland, Israel, Italy, Japan, Jordan, Korea, Latvia, Lithuania, Luxembourg, Malaysia, Mexico, Morocco, Netherlands, New Zealand, Norway, Paraguay, Peru, Poland, Portugal, Romania, Russian Federation, Saudi Arabia, Singapore, Slovakia, Slovenia, South Africa, Spain, Sweden, Switzerland, Tunisia, Turkey, United Kingdom, United States and the European Union. Participation typically varies somewhat depending on the issues being discussed.

Some empirical and policy questions were raised for possible consideration by governments in the context of the Roundtable discussion. The questions can suggest potential new areas for fact-finding, identify policy issues, or raise questions relating to the text of the paper. They are included for reference in Annex 1.

3 As in Roundtable work generally, the term investment treaties is used for convenience to refer both to stand-alone investment treaties and to the investment chapters in broader treaties such as trade and investment agreements.

See OECD, "Fair and Equitable Treatment Standard in International Investment Law", OECD Working Papers on International Investment, 2004/03; OECD, Indirect Expropriation and the Right to Regulate in International Investment Law, OECD Working Papers on International Investment, 2004/04.

5 The paper mentions investor expectations only in reference to a single case. OECD, "Fair and Equitable Treatment Standard in International Investment Law", OECD Working Papers on International Investment, 2004/03, p. 38. 
paper begins examining government action to address the balance between investor protection and the right to regulate. ${ }^{6}$

The first section below seeks briefly to present some aspects of the debate over treaties and the right to regulate in some jurisdictions. Governments are naturally attuned to this debate in their own jurisdictions, but it may be helpful to understand views in other jurisdictions as well. The section is merely illustrative and additional issues may be at issue in many jurisdictions.

The second section notes that policy analysis today is increasingly focused on the impact of individual rules rather than treaties as a whole. Some reasons for this evolution are explored as are the potential benefits for policy makers of the more intensive analysis.

The third section provides a brief introduction to four broad concepts put at issue by the mandate given by the Roundtable: (a) regulation; (b) investor protection; (c) the impact of treaties on regulation and the question of "regulatory chill"; and (d) balancing investor protection and the right to regulate. The analysis is only introductory, but breaking down these broad concepts leads to the identification of a significant number of issues and questions for analysis and discussion.

Given the focus on protecting the right to regulate in most recent government action relating to treaties, that aspect is given some priority, but the value of reducing regulatory risk for investors is also underlined. Some have pointed to a risk of "overshooting" in efforts to correct the balance in treaties towards allowing greater space for a right to regulate. Others have noted that the right to regulate is subject to many constraints other than investment treaties including under domestic constitutions and administrative law, and that these provisions can protect investors.

At this initial stage, ISDS is generally excluded from the analysis. The Roundtable has engaged in considerable analysis of ISDS and the Secretariat is engaged in further analysis of ISDS as part of a specific mandate from the Roundtable. ${ }^{7}$ In contrast, policy issues raised by substantive law are largely a new area for the Roundtable and deserve priority attention in the first instance.

While for these reasons ISDS is initially excluded here as a general matter, it is important to recognise that the ISDS system is a core part of the debate over the impact of treaties on the right to regulate. Indeed, for some critics, textual reforms to treaties and government input into interpretation are insufficient to overcome the impact of characteristics of ISDS such as the important role of commercial arbitrators, perceived conflicts of interest or lack of accountability. Governments have also recognised links between ISDS and the right to regulate, and are considering or have engaged in a number of reforms of ISDS to address concerns. ${ }^{8}$ Accordingly, the exclusion of ISDS should be seen

6 David Gaukrodger, Addressing the Balance of Interests in Investment Treaties, OECD Working Papers on International Investment 2017/3.

7 David Gaukrodger \& Kathryn Gordon, "Investor-State Dispute Settlement: A Scoping Paper for the Investment Policy Community", OECD Working Papers on International Investment, 2012/03; FOI Roundtable 21, Summary of discussion, p. 8 (Oct. 2014).

On 16 September 2015, the European Commission proposed a new Investment Court System for its negotiations on the Transatlantic Trade and Investment Partnership (TTIP) and ongoing trade and investment agreement negotiations. The EU Trade Commissioner has described the ICS as a way to help "enshrine government's right to regulate". See Blog by Cecilia Malmström on Proposing an Investment Court System (2015). The Commission also announced that it will start work on a permanent International Investment Court, together with other countries. In November 2015, the EU released its proposed text for the investment chapter of TTIP including a standing investment court 
as for analytical purposes rather than as suggesting that it is not relevant to the question of balancing. It is important to bear in mind throughout that treaty content is not applied to host governments by omniscient beings, but rather by specific institutions or ad hoc mechanisms with their own strengths and weaknesses.

\section{The balance between investor protection and the right to regulate is a central issue in current debates and policies concerning investment treaties}

Both critics and defenders of the current approach to treaties regularly refer to the issue of the balance of investor protection and the right to regulate. No attempt is made here to capture the full scope of the debate, but a few illustrations of different views may provide helpful context for Roundtable discussions.

International law scholar Martti Koskenniemi has criticised the impact of TTIP as a transfer of regulatory power away from national public authorities to arbitrators. In his view, "[e]ssentially, it's a transfer of power from public authorities to an arbitration body, where a handful of people would be able to rule whether a country can enact a law or not and how the law must be interpreted."

Critics point to a number of cases and claims that in their view illustrate how the right to regulate in key areas is now excessively subjected to the rulings of arbitrators in ISDS. These include for example the 4.7 billion euro claim by Vattenfall against Germany under the Energy Charter Treaty relating to Germany's decision to accelerate the phase out of nuclear power after Fukushima. ${ }^{10}$

High-profile critics such as Nobel-prize winning economist Joseph Stiglitz have criticised a perceived transformation of the purpose of investment treaty provisions. These critics suggest that treaty provisions are no longer designed to protect property rights in exchange for foreign direct investment (FDI). They have instead become a weapon to fight regulation:

Perhaps the most invidious - and most dishonest - part of such [trade] agreements concerns investor protection. Of course, investors have to be protected against the risk that rogue governments will seize their property. But that is not what these provisions are about. There have been very few expropriations in recent decades, and investors who

and appellate tribunal. In December 2015, the EU and Viet Nam concluded negotiations on a free

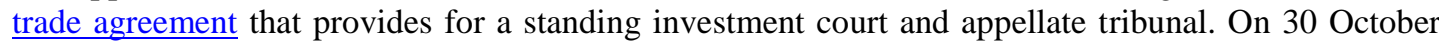
2016, Canada and the EU and its Member States signed the Comprehensive Economic and Trade Agreement (CETA) which also provides for a standing investment tribunal and appellate tribunal.

See also United States Trade Representative, Trans-Pacific Partnership: Summary of US Objectives ("Procedures for arbitration... would provide strong protections to ensure that all TPP governments can appropriately regulate in the public interest, including on health, safety, and environmental protection. This includes an array of safeguards designed to raise the standards around investor-state dispute settlement, such as by discouraging and dismissing frivolous suits, allowing governments to direct the outcome of arbitral tribunals in certain areas, making proceedings more open and transparent, and providing for the participation of civil society organizations and other non-parties.").

Jussi Konttinen \& Alexsi Teivainen, Professor: Finland's legislative power may be in jeopardy, Helsinki Times (15 December 2013).

See also see CEO/TNI, The Right To Say No, Issue Brief, May 2013 (addressing perceived threat from CETA to fracking ban). 
want to protect themselves can buy insurance from the Multilateral Investment Guarantee Agency, a World Bank affiliate (the US and other governments provide similar insurance)....

The real intent of these provisions is to impede health, environmental, safety, and ... even financial regulations.... ${ }^{11}$

Proponents of existing treaties take a very different view. Some have suggested that the key issue for treaties is to protect covered investors from abuse of the right to regulate. They are concerned that a right to regulate can be exercised to the detriment of investor rights. These views are illustrated for example by the submission of the European Federation for Investment Law and Arbitration (EFILA) to the recent European Commission consultation on TTIP:

Q5 - Ensuring the right to regulate and investment protection

1. EFILA is of the opinion that the approach chosen by the Commission is not well suited for the purpose of balancing the right to regulate and protection of investments and investors. Its main flaws are that it opens the door for abuses by Contracting Parties and limits the rights of investors and the freedom of interpretation of arbitral tribunals. In order for the ISDS to serve its purpose, arbitral tribunals' freedom of interpretation of the treaties' should be safeguarded. The process of appointment ensures selection of independent and impartial arbitrators and there is no need to limit their freedom of interpretation. The current practice clearly indicates that arbitral tribunals faithfully follow rules of interpretation prescribed in the Vienna Convention on the Law of Treaties.

2. The relationship between the protection of investments and the right to regulate should be clarified as to elucidate the rights and obligations of Contracting Parties in order to avoid abuse of the "right to regulate". This right should be exercised in full observance of the rule of law and in full respect for the rights of investors.

3. There is no need to include explicit provisions concerning the right to regulate as this can be done through careful drafting of the protection standards and exceptions. Furthermore, the arbitral tribunals have always balanced the rights of the state involved with the rights of the investor. ${ }^{12}$

Some legal commentators consider that the government's right to regulate is not actually at risk under current investment treaties:

[The] characterization [that investment treaties constrain policy space] is wholly misleading. Arbitrators have nothing to say about the "permissible scope of public powers." The authority to regulate remains intact, and arbitrators decide only whether an investor is entitled to compensation because a state breached an obligation it

11 Joseph Stiglitz, The Secret Corporate Takeover, Project Syndicate (13 May 2015).

12 See European Federation for Investment Law and Arbitration (EFILA), TTIP Consultation Submission (undated). 
undertook — in an exercise of its sovereign capacity — by concluding a treaty. There is no foundation for the characterization that investment tribunals are a back door to dismantling environmental regulations or that they substitute their own policy judgment for that of democratically elected governments". ${ }^{13}$

Business groups have also taken an active part in the debate over the right to regulate. For example, the United States Council on International Business (USCIB) has contended that existing treaties achieve a proper balance:

ISDS does not limit the policy space of states to introduce new regulation. Instead, it helps establish a balance between the right of States to regulate and the rights of investors to protection under international law. Contrary to some suggestions, investors cannot use investment provisions to bring a claim against a state just because their profits might be affected by a new government policy. ${ }^{14}$

In response to these and many other views, governments have taken a variety of positions in the public debate. Some governments, like the US, have defended their treaty practice as being particularly attentive to the protection of the right to regulate:

The United States has been a leader in developing carefully crafted ISDS provisions to protect the ability of governments to regulate ....

These provisions are different - and stronger - than the provisions in many other investment agreements in which the United States is not a participant. It's important to understand how U.S. agreements differ from other agreements that do not meet the same standards. ...

\section{Protect the right of governments to regulate in the public interest.}

The United States wouldn't negotiate away its right to regulate in the best interest of its citizens, and we don't ask other countries to do so either. Our investment rules preserve the right to regulate to protect public health and safety, the financial sector, the environment, and any other area where governments seek to regulate. ${ }^{15}$

US officials have also suggested that the US will seek to further raise its standards protecting the right to regulate in treaties currently under negotiation:

$\mathrm{Th}[\mathrm{e}]$ thousands of [investment] agreements contain a wide range of standards, some that strongly protect a government's right to regulate, others that do not. The U.S. has been at the leading edge of updating, upgrading and clarifying these standards; protecting the right to regulate; and drawing lessons from previous agreements to ensure

13 Charles N. Brower \& Sadie Blanchard, What's in a Meme? The Truth about Investor-State Arbitration: Why It Need Not, and Must Not, Be Repossessed by States, Columbia Journal of Transnational Law, Vol. 52, N. 3, p. 748 (citations omitted).

United States Council on International Business, Bilateral Investment Treaties and Investor-State Dispute Resolution: Six Key Facts.

United States Trade Representative, The Facts on Investor-State Dispute Settlement (March 2014). 
that our agreements have the highest possible standards. TPP incorporates and builds on those efforts and goes beyond them by:

Further raising the standards: TPP will make it absolutely clear that governments can regulate in the public interest, including with regard to health, safety and the environment, and narrowing the definition of what kinds of injuries investors can seek compensation for. ${ }^{16}$

For some governments with existing treaties, concerns about a lack of balance in their existing treaties have been a significant factor in changes to their treaty policy. South Africa's revised investment policy followed a review concluding that its BITs and international arbitration pose unacceptably high risks to the government's right to regulate in the public interest. ${ }^{17}$ Commentators have noted that India's reconsideration of its BIT programme was related to concerns about Indian BITs not balancing investment protection with India's regulatory power. ${ }^{18}$

The European Commission consultation on the TTIP investment provisions specifically inquired about views about the impact of the provisions on the right to regulate. ${ }^{19}$ The staff review of the 150,000 responses to its consultation on the TTIP investment provisions identified "the protection of the right to regulate" as an area where further improvements should be explored. ${ }^{20}$ In presenting the report, the Commissioner for Trade, underlined that " $[\mathrm{t}]$ he European Commission would never even consider an agreement which would ... limit our governments' right to regulate. Neither would EU Member States, nor the European Parliament". ${ }^{21}$ Other governments such as Malaysia and Canada have affirmed in general terms that a particular proposed treaty under negotiation or a recently signed treaty will protect the right to regulate. ${ }^{22}$

Jeffrey Zients, Investor-State Dispute Settlement (ISDS) Questions and Answers, White House Blog (26 Feb. 2015).

17 See, e.g., Xavier Carim, South Africa and Bilateral Investment Treaties (6 Sept. 2013), p. 8.

See Prabhash Ranjan, India and Bilateral investment Treaties: A Changing Landscape, 29(2) ICSID Review - Foreign Investment Law Journal (2014), 419-450.

See European Commission, Public consultation on modalities for investment protection and ISDS in TTIP, pp. 25-30.

European Commission, Commission Staff Working Document, Online public consultation on investment protection and investor-to-state dispute settlement (ISDS) in the Transatlantic Trade and Investment Partnership Agreement (TTIP), SWD(2015) 3 final (13 January 13 2015), p. 4.

See Report presented today: Consultation on investment protection in EU-US trade talks (13 January 2015); see also European Parliament resolution of 8 July 2015 containing the European Parliament's recommendations to the European Commission on the negotiations for the Transatlantic Trade and Investment Partnership (TTIP) (2014/2228(INI)) (8 July 2015) art. 2(c)(xiv) ("standards of protection and definitions of investor and investment should be drawn up in a precise legal manner protecting the right to regulate in the public interest"); id. Recital P ("whereas now that the results of the public consultation on investment protection and ISDS in the TTIP are available, a reflection process taking account of the contributions - is currently being undertaken within and between the [European Commission, the Council and the Parliament], while exchanging with civil society and the business sector, on the best way to achieve investment protection and equal treatment of investors while ensuring states' right to regulate").

See, e.g., Ministry of International Trade and Industry, Malaysia, Media Statement: Trans-Pacific Partnership Agreement (TPP) (29 July 2015) §§ 12-17 (noting that "[o]ne of the main concerns over the [Trans-Pacific Partnership Agreement - TPPA] is [that] the inclusion of [ISDS] would impinge on 
One of the most thorough publicly-available reviews of investment treaty policy by a government agency has been conducted by the Australian Productivity Commission. ${ }^{23}$ In its most recent annual report on trade policy, the Commission recommended a number of improvements to cost-benefit analysis for trade agreements, including attention both to regulatory chill and to future contingent liabilities from ISDS:

To close the evaluation gaps a more comprehensive and robust evaluation methodology carried out independently and with transparency is needed. ... The prospect of inducing regulatory chill through new treaty obligations would also feature prominently as would the contingent liabilities created by the agreement. A key example of the latter is the operation of an investor-state dispute mechanism. $^{24}$

\section{Policy analysis of investment treaties is increasingly focused on the impact of individual rules rather than treaties as a whole}

Policy analysis of investment treaties has often been focused on the impact of treaties as a whole. There is for example a substantial amount of analysis about whether treaties encourage FDI. However, it is increasingly directed at the impact of specific rules. It is useful to refer to rules rather than treaty provisions because a single clause like a fair and equitable treatment (FET) provision can have widely varying content depending on interpretation. Some interpretations extend its coverage to eight or more different rules. (The issue or whether particular norms are best characterised as rules or standards is deferred.)

While policy analysis generally addressed treaties as a whole, legal commentators have engaged in intensive analysis of the individual rules. They have frequently reported and analysed the interpretations provided by arbitral tribunals, including the development of new rules found to be applicable. Legal analysis of treaties and arbitration cases, however, rarely engages in policy analysis. ${ }^{25}$

Malaysia's sovereignty and limit the policy space of Government to regulate, while providing the right to investors to sue governments" and stating that the "TPPA does NOT prevent Governments from pursuing and regulating legitimate public policy objectives, especially in areas such as national security, public health, environment and welfare" and that there are safeguards being negotiated to address key concerns); Department of Foreign Affairs, Canada, Canada-China Foreign Investment Promotion and Protection Agreement (FIPA) Negotiations ("The FIPA will preserve the right of both Canada and China to regulate in the public interest.").

The Productivity Commission is the Australian Government's independent research and advisory body on a range of economic, social and environmental issues affecting the welfare of Australians. Its work program is largely but not entirely determined by the government. It provides policy advice to the government which is considered along with other inputs in formulating policy.

Productivity Commission, Trade \& Assistance Review 2013-14 (2015), pp. 86, 87. The Productivity Commission analysed trade and investment treaty policy in a 2010 report. Bilateral and Regional Trade Agreements, Productivity Commission research report (November 2010). It does not currently have a work program on investment treaty issues or a formal review function with regard to free trade agreements. reflects this dichotomy between policy analysis and legal analysis. ISDS cases allowing shareholder 
Today, however, there is increasing interest in legal, institutional and economic analysis of individual rules. Large awards and claims based on specific rules obviously draw significant attention, particularly where the rules are not set out in the treaty text. Increasing comparison of rules applied under treaties to domestic law rules also leads to greater attention to individual rules, especially where it is contended that they provide greater benefits to covered investors than those available under domestic law.

The extension of some versions of FET into issues of stability of regulation and due process, together with the difficulties of demonstrating achievement of the goal of increasing FDI, has been accompanied by new policy arguments about treaty benefits, costs and effects. Treaties and in particular rules applicable under the FET clause, it has been argued, can make positive contributions to governance and the rule of law, policy goals that appeared to be largely absent from early treaty policy. These claims are disputed and the debate has drawn further attention to the impact of individual rules.

Some commentators have suggested that a more individualised approach to evaluating rules will improve the quality of the debate over the right to regulate:

A prominent issue among trade policy wonks and academics these days is whether trade and investment agreements undermine what is often referred to as governments' "right to regulate." The idea is that governments have a "right" to take certain regulatory actions, and that international economic agreements may interfere with this right. ...

Unfortunately, the term "right to regulate" is misleading, as it glosses over key distinctions in how international economic law rules affect domestic regulation. It is true that such international rules do affect regulation; but they do so in much more nuanced ways than the debate acknowledges, and the nuances are important here. In simple terms, international rules may identify and prohibit one particular policy goal (e.g., protectionism) that regulations might pursue; or, in the alternative, they may hold every policy goal open to review under a broader standard that gives international courts significant oversight power. It is this distinction that holds the key to the debate, but it is often ignored.

One of the core functions of international law is to impose constraints on states, requiring them to do, or not do, certain things. Thus, by its nature, international law affects domestic actions, including regulation. The question for the trade policy debate is: how does international economic law affect domestic regulation? It does so in a variety of ways, each with its own particular impact. ${ }^{26}$

claims for reflective loss (unlike the rules in domestic law) have been extensively analysed in terms of legal doctrine with a number of commentators pointing to the outcomes in cases and the potential for claims for reflective loss that the interpretations made possible. However, there has been little or no attention to policy issues in this analysis. See David Gaukrodger (2013), "Investment Treaties as Corporate Law: Shareholder Claims and Issues of Consistency", OECD Working Papers on International Investment, 2013/03, pp. 29-31.

Simon Lester, Talk of a "Right to Regulate" is Hurting the Trade Debate (Cato Institute commentary, 21 July 2015). 
Closer policy analysis of individual rules has in fact recently become more prevalent. Economists, political scientists as well as legal scholars are now engaging in intensive efforts to evaluate the impact of individual rules. ${ }^{27}$ This is unquestionably a helpful development from an analytical perspective. Investment treaties typically gather together a series of rules. There is little reason to think that all of the rules have the same effects on policy merely because they are included in an investment treaty. The policy issues raised by a rule that requires compensation for a forced sale of property from one owner to another -- a direct expropriation - are significantly different from those raised by rules requiring compensation for certain types of regulatory measures. Provisions facilitating capital flows similarly raise different policy issues.

Specific treaty clauses addressing the right to regulate are also a key component of analysis in this area. Research can address their frequency of use and establish typologies. Some have suggested that broad right to regulate clauses in treaties could create new interpretive uncertainties. While research is necessary, it does not appear that the clauses of this type have figured prominently in many ISDS cases to date. Most cases still appear to turn on the interpretation of core provisions such as FET.

A companion paper on government action to address the balance in investment treaties examines some individual rules often alleged to be part of FET. It focuses on government views about the nature of a specific version of FET that is increasingly popular -- one limiting FET to the minimum standard of treatment under customary international law -- and their views about the individual rules that it contains. $^{28}$

\section{Comparative analysis}

As in other Roundtable work on treaties, comparative analysis can be instructive. ${ }^{29}$ For example, the impact of the WTO system on the regulatory autonomy of governments has been addressed in treaty drafting, negotiations, and extensive analysis and debate. ${ }^{30}$ The preamble to the WTO General Agreement on Trade in Services (GATS) recognises "the right of governments to regulate, and to introduce new regulations on the supply of services within their territories in order to meet national policy objectives". ${ }^{31}$ It also recognises "the particular need of developing countries to exercise [the right to regulate services] given the differing levels of existing regulation of services in different countries". As Trebilcock et al. note, this right to regulate is qualified by specific GATS disciplines and those negotiated in the future, and its contours are thus unclear. ${ }^{32}$ Negotiations pursuant to particular GATS provisions such as the domestic regulation provision have generated extensive debate

27 See, e.g., Jonathan Bonnitcha, Substantive Protection under Investment Treaties: A Legal and Economic Analysis (2014).

David Gaukrodger, Addressing the Balance of Interests in Investment Treaties, OECD Working Papers on International Investment 2017/3.

See FOI Roundtable, ISDS Progress report, p. 5.

The WTO is used here as an example, but comparisons with other systems may also yield valuable insights.

WTO, General Agreement on Trade in Services.

Michael Trebilcock, Robert Howse and Antonia Eliason, International Trade Regulation (4th ed. 2012), pp. 496-97 ('this 'right to regulate' is subject to any specific limitation or disciplines as exist or may be negotiated; thus the 'right to regulate' begs the critical question of how little or how much the exercise of this right will be constrained or qualified by any particular set of GATS disciplines"). 
about the right to regulate. ${ }^{33}$ As with investment treaties, the debate in the WTO context has focused both on the rules and the competence and legitimacy of adjudicators. ${ }^{34}$

Comparative analysis and debates can be instructive, but key differences must be borne in mind. For example, the state-to-state dispute settlement mechanism in WTO gives rise to fewer claims than ISDS. ${ }^{35}$ As the Roundtable has previously noted, WTO disputes do not involve money damages or claims for lost profits. A successful claim normally results in withdrawal of a WTO-inconsistent measure. ${ }^{36}$ There are many significant differences in substantive law. Nonetheless, the context of increasing interconnectedness of trade and investment, and of trade and investment negotiations, invites careful comparative analysis on important issues of public interest.

\section{Preliminary outline of issues}

This section addresses four issues: (a) regulation; (b) the impact of treaties on regulation; (c) investor protection; and (d) the balancing of invention protection and the right to regulate. A key goal at this stage is to identify questions and issues for theoretical and empirical analysis and discussion. This preliminary analysis is defined to some degree in the first instance by the parameters of the debate over the right to regulate. Over time, Roundtable analysis and discussion can refine the nature and degree of the right to regulate issues in different contexts.

\section{A. Regulation}

Analysis of the impact of investment treaty rules on regulation can usefully distinguish between different types or forms of regulation, and between regulation in different sectors.

1 .

Types and forms of regulation

Under most treaties, practically all national law can be subject to the international law constraints in investment treaties. The range of measures under review or at issue can include relevant provisions of national constitutions ${ }^{37}$, legislation adopted by Parliaments, legislation adopted by federal states or

33 See GATS art. VI:4; Trebilcock et al, p. 496 ("Hugely important issues of regulatory autonomy and democratic legitimacy are at stake in the [WTO] negotiations on domestic regulation.") WTO cases have also addressed the right to regulate. See id. 496-497.

See, e.g., Gaetan Verhoosel, National Treatment and WTO Dispute Settlement: Adjudicating the Boundaries (2002), pp. 1,8 (in considering the impact of the WTO on the regulatory autonomy of governments, the inquiry involves not only establishing the relevant rule, but inquiring into legitimacy of having the rule applied by the existing institutional structure for adjudication); Trebilcock et al, p. 294 (noting issues about capacity of adjudicatory system to handle issues involving a high level of scientific and technical knowledge); Peter van den Bossche, The Law and Policy of the World Trade Organization (2d ed. 2008), ch. 7.

The WTO received 14 requests for consultations in 2014, not all of which necessarily give rise to a claim. WTO 2015 Annual report, p. 92. UNCTAD has reported 70 new ISDS claims in 2015 and others may not be public. Some measures, like Australia's tobacco plain packaging requirements, have been at issue in both systems.

For the different approaches to dispute resolution, see generally ISDS Scoping Paper, pp. 10-12 \& Annex 2.

It does not appear that any case has involved alleged breaches of a treaty by a constitutional provision although more research is required. Governments have argued that particular treaty interpretations would violate their Constitution. For example, in the recent Charanne v. Spain case involving 
provinces, regulations of many kinds, as well as the application of the law in individual cases. Claims arising from these different types of regulation can raise different policy issues. This section will address some issues arising from arbitral review of legislation, administrative measures and domestic courts.

The impact of investment treaties on the right to regulate is often perceived to be greater when cases involve review of legislation adopted by parliaments. Such cases involve the interaction of investment treaties with democratic decision-making in acute form. The question of how frequently ISDS cases have evaluated parliamentary action is debated. ${ }^{38}$ Many cases involve various elements of regulatory action and can be interpreted as challenges at different levels. But there is no doubt that challenges to laws are possible under the broad provisions of many existing treaties, and they occur with some frequency.

A substantial number of ISDS cases have involved challenges to regulatory measures. Many treaties do not require claimants to exhaust domestic remedies - under such treaties, covered investors can sidestep the domestic courts and proceed directly to arbitration to challenge regulatory action. Certainly once a dispute breaks out if not before, investors naturally place a high value on direct access to ISDS as it provides greater leverage and potentially quicker access to a remedy. However, it can be seen as interference with regulation by depriving the national law system of the opportunity to self-correct. If domestic court review is sidestepped, it may exacerbate the risk of an ISDS tribunal acting as a court of appeal because it may need to resolve disputed issues of national law. It can also be seen as inviting numerous claims for damages especially where domestic law excludes damages while ISDS would allow a claim for lost profits. Since ISDS is generally much more costly than domestic administrative law litigation, it can also raise costs.

Governments have adopted a number of approaches in this area. A number have expressed a preference for having most challenges to regulatory measures resolved in the domestic courts rather than in ISDS. Others have sought to limit or exclude concurrent proceedings in the domestic courts and in ISDS on the same measure. These various policy options are reflected in "fork in the road" clauses, "no u-turn" provisions or requirements for recourse to domestic remedies as a conditions for access to arbitration. In addition to procedural requirements, some substantive rules may require that the government have had a reasonable opportunity to correct the situation and have failed to do so as a condition for liability. It is important to consider whether and how these different approaches may affect regulation.

Courts play a variety of roles with regard to regulation and their relative importance can vary between countries. Courts interpret, apply and enforce domestic law. Courts also resolve challenges to the legality of administrative action under domestic law, typically in judicial review-type proceedings with non-pecuniary remedies. This is a core function of courts in the administrative state. Courts can

shareholder claims for reflective loss, the tribunal rejected the argument that the public order and equality provisions in the Spanish Constitution would be violated by treaty provisions if they were to allow certain Spanish citizens (physical persons who own the shares in the foreign claimant) access to a dispute resolution mechanism with certain procedural characteristics (possibility to choose members of the tribunal, application of more flexible procedures) to which other Spanish citizens do not have access. See Charanne BV v. Spain, majority award (21 Jan. 2016), paras. 419-423.

It has been suggested that depending on how decisions are coded, the percentage of decisions seen as involving challenges to legislation can vary from $9 \%$ to $37 \%$. See European Federation for Investment Law and Arbitration (EFILA), A response to the criticism against ISDS (17 May 2015); Reply to Efila (6 July 2015) (post by Professors David Schneidermann, Kyla Tienhaara and Gus van Harten). 
also play a role in developing regulatory standards. Generally, this occurs in an interstitial fashion as courts interpret statutes and their interaction with other law. More rarely, courts can be the source of significant revisions in applicable regulation, such as when a court changes its approach to a particular question. Some ISDS claimants have brought claims asserting that a national court has allegedly made a change of this nature and that such a change is wrongful under an investment treaty.

Some ISDS review of domestic court adjudication involves limited impact on the broad exercise of the right to regulate. Traditional rules protecting investors from denial of justice in adjudicatory proceedings are generally seen as being primarily focused on an inquiry into whether there was a serious breakdown in the procedural quality of the domestic court system in a particular case; review on this basis has limited effects on regulatory autonomy. However, this type of limitation to a specific type of government action appears to be rare in the current body of investment treaties. Much thus depends on the scope of applicable substantive protections under treaties.

Differences between domestic law and treaty standards raise particular issues for ISDS review following domestic court action. A domestic court may uphold or enforce under domestic law an administrative decision that is legal under domestic law but allegedly contrary to an investment treaty. Some commentators have suggested that the only wrongful act at issue in such cases is the original administrative act because the domestic courts have merely properly carried out their duty under national law. ${ }^{39}$ Parsing out the degree to which allegedly improper action is that of a court as opposed to an administrative body or a legislature, and applying different standards or excluding review as appropriate, can involve delicate issues. To take one example, the application of time limits on claims, such as a three year limit, could provide an incentive for claimants to go directly to arbitration rather than the domestic courts if the "clock" is considered to start from the date of the allegedly wrongful administrative act rather than on the date when it was upheld by the courts under domestic law. While judicial review generally moves fairly quickly, three years may be insufficient to reach a final decision on appeal.

The interaction of ISDS review and domestic courts has become a sensitive issue. The Chief Justice of the High Court in Australia recently wrote that "the significance of ISDS arbitral processes is global. They have general implications for national sovereignty, democratic governance and the rule of law within domestic legal systems. Their long-term consequences for national judiciaries cannot be stated with confidence". ${ }^{40} \mathrm{He}$ has proposed consideration of "precluding the canvassing in an arbitral proceeding of the correctness of a decision of an Australian domestic court ...".

The discussion here assumes that the domestic court is not empowered to apply investment treaty norms. In some cases, such as where the treaty is incorporated into domestic law or where the courts can directly apply international law norms, the domestic courts may rule not only on the domestic law legality of the measure, but also its consistency with an investment treaty.

Robert S. French, Investor-State Dispute Settlement - A Cut Above the Courts? (9 July 2014). Chief Justice Roberts of the US Supreme Court has referred in similar terms to the scope of investment arbitration review being broad in describing its application, including to the judiciary: "by acquiescing to [investment] arbitration, a state permits private adjudicators to review its public policies and effectively annul the authoritative acts of its legislature, executive, and judiciary". BG Group plc v. Republic of Argentina, 134 S.Ct. 1198, 1220 (2014) (dissenting, citation omitted).

Robert S. French, Trade Law and the Australian Courts, Law Council of Australia, International Trade Law Symposium 2014, p. 11. 
Evaluation of the impact of treaties on the right to regulate may require careful attention to the types of regulation at issue. At present, investment treaties appear rarely to distinguish between types of government action.

\section{Regulation in different economic areas}

In some cases, discussion about the impact of treaties on the right to regulate has focused on their impact in particular areas. A growing range of treaty provisions establish special regimes for particular areas. It appears that most if not all of these provisions limit or qualify the application of the general protection provisions rather than expanding them. The Roundtable has considered some provisions for greater government voice (such as filtering mechanisms) applicable in areas such as tax or financial services. ${ }^{42}$ Other areas of particular interest could include the regulation of tobacco.

Special protections can include a wide range of provisions. An innovative example is the regime for financial services and in particular prudential regulation under the Comprehensive Economic and Trade Agreement (CETA) between Canada, the European Union and its Member States. In an initial draft dated 26 September $2014^{43}$, the regime had at least four types of special features as set forth in the Draft and an accompanying Understanding: (i) special dispute settlement provisions under which all three arbitrators are appointed from a government-appointed roster of arbitrators with financial services expertise ${ }^{44}$; (ii) a complex filtering mechanism with two tiers of intergovernmental committees that can determine whether a claim proceeds to arbitration; (iii) an explicit and highly deferential standard of review based on the highly specialised nature of the regulation at issue ${ }^{45}$; and (iv) delegated power to amend the Understanding given to an inter-governmental committee. ${ }^{46}$ The 2016 CETA agreement as signed by the Parties replaces investor-state arbitration as the general

$42 \quad$ Kathryn Gordon \& Joachim Pohl, "Investment Treaties over Time - Treaty Practice and Interpretation in a Changing World", OECD Working Papers on International Investment, 2015/02, OECD Publishing, p. 26.

The 26 September 2014 CETA Draft is available on government and private websites.

For certain financial services cases, arbitrators are appointed from the government-appointed panel even if some governments have not supplied their nominees. If the roster is not fully created, the tribunal is selected from those named to the roster by "one or both" of the governments (2014 CETA Draft, Financial Services Chapter, art. 20 Investment Disputes in Financial Services). A government can be expected to name its members once it faces a claim; the other Party is likely to follow suit and in any event the arbitrators can be chosen from the roster. These provisions thus appear effectively to address the issue of possible government reluctance to constitute rosters called for by treaties. See NAFTA, art. 1124(4) (requiring constitution of a roster of arbitrators appointed by the treaty Parties, but not resulting in the actual constitution of a roster).

An Understanding attached to the draft establishes a highly deferential standard of review: "given the highly specialized nature of prudential regulation, those applying these principles shall defer to the highest degree possible to regulations and practices in the Parties' respective jurisdictions and to the decisions and factual determinations, including risk assessments, made by financial regulatory authorities" (2014 CETA Draft, Annex XX of the Financial Services Chapter). For ISDS in general, there was only an instruction for a Committee to consult on standards of review (2014 CETA Draft, art. 42, p. 180).

See below section IV.D.4.b for a discussion of standards of review.

See 2014 CETA Draft, Annex XX of the Financial Services Chapter, Periodic Review. 
regime for investor-state disputes with a permanent tribunal and appellate tribunal, but maintains a number of the features of the special regime for financial services. ${ }^{47}$

Regimes that protect specific areas raise a number of issues. They can increase the complexity of treaties (although treaties remain very general compared to national regulation). Governments sometimes point to the special regimes as being particularly effective in protecting the right to regulate in that area or as being required due to the special expertise of regulators. ${ }^{48}$ Advocates for the protection of regulatory power in other sectors, however, may consider that similar protections are also appropriate for their sectors. They may argue that the recognised need for the special regimes demonstrates that the general provisions place other sectors at risk. They may also consider that the degree of specialised expertise at issue is at least equal to that in protected sectors.

Sectoral analysis is an important element of the balancing debate. However, the initial inquiry has focused on the impact generally. This should allow a better appreciation of how the general provisions affect the right to regulate in particular sectors and how that impact is affected by special regimes.

\section{B. Treaty protection for foreign investors}

It is important that investors have access to recourse against governments. Governments can and do expropriate investors or discriminate against them. Investors can be protected under domestic judicial and administrative systems. Investment treaty provisions give substantial additional leverage to covered foreign investors in their dealings with host governments.

Investment protection is not the only policy goal associated with investment treaties. Treaties are commonly seen as instruments designed to serve broader purposes such as the encouragement of foreign investment. Preambles of investment treaties often list encouragement of foreign investment as one of their explicit objectives, and it is still an often-cited argument in the discussion on the merits of investment treaties. However, efforts to prove that such objectives are achieved have not been conclusive. Investment treaties can also potentially have a positive impact on domestic and global governance and government accountability more generally although this is also both uncertain and disputed.

Protection for covered foreign investors at issue in the analysis here includes the full range of protections included in existing treaties and could extend to potential new protections if they emerge. The impact of existing and potential provisions on the right to regulate can be a key factor in evaluating them from a policy perspective. While all provisions are thus of relevance, it is clear, as outlined below, that today some are more central than others to the debate over the right to regulate. The FET provision, for example, is at the core of the right to regulate debate. A number of other provisions, such as those governing national treatment, most-favoured nation, indirect expropriation or capital flows are also important, but an initial focus on FET is warranted by its prominence.

47 See, e.g., 2016 CETA (30 October 2016), arts. 13.21(2), 13.20(3)-(4) (roster of adjudicators with financial services expertise appointed by governments; provision for a division of the Tribunal to be formed from the roster in certain financial services disputes); id. art. 13.21(2) (provision for appointment of individuals proposed for the roster by one or both Parties in the event the roster is not constituted); id. Annex 13-B (two-tier filtering mechanism by inter-governmental committees for certain financial services claims); id. Annex 13-B, art. 8(c) (deferential standard of review).

Frank Hoffmeister, A First Glimpse of Light on the Emerging Invisible EU Model BIT, The Journal of World Investment \& Trade, vol. 15 (2014), p. 398. 
Different levels of protection for different investors may complicate the regulatory process. This can occur where a government has multiple treaties with different investor protection provisions. Many governments have sought to define model treaties with a well-defined and consistent level of exposure to covered investor claims in part for this reason. Others are engaged in reform processes after agreeing to a range of treaties with differing provisions. ${ }^{49}$ The regulatory complexity of differing treaties can be a particular problem for developing countries because of the complexity of managing the differing rights of different investors. Some investors may have protection from significant nondiscriminatory changes to the regulatory framework for a public purpose on the basis of reliance on the earlier framework, others may have protection if they received "specific commitments", and others may have no protection from such non-discriminatory regulations. These differences in rights may complicate decisions on policy changes to address issues like climate change that may impose substantial costs on investors. ${ }^{50}$

Similarly, differences between the levels of protection of investors also occur between covered and non-covered investors (including domestic investors) as a result of differences between treaty rules and domestic law. Criticism of investment treaties for interfering with a level playing field for investment has mainly focused on perceived detrimental effects on the efficiency of investment decisions and investors (distorting effects of regulatory preferences, increased transactions costs, inequalities for small and medium enterprises (SMEs)) or fairness. But the impact on regulatory processes also merits attention.

The duration of the investment protections in investment treaties may also affect the right to regulate. Investment treaties routinely have a duration that lasts over the course of several elections; free trade agreements (FTAs) that include investment chapters can be even more permanent in practice. ${ }^{51}$ Consequently, investment treaties concluded by one government can bind future governments without the latter having the ability to terminate the treaty. Where treaty policy is consensual in a given country, this lengthy duration is unlikely to raise issues. However, where there are differences between competing political parties about the value of treaties, or their content, this lengthy duration may exacerbate concerns about the impact of treaties on the regulatory autonomy of future governments.

49 See, e.g., FOI 21, Summary of discussion, p. 9 (Indonesia explained that key problems leading to its decision to reform its treaty policy included the lack of a uniform template and outdated treaties.)

Some commentators have suggested that the best policy to address this complexity is to govern in accordance with the treaty and/or arbitral interpretation providing investors with the most expansive rights (in part because most-favoured nation (MFN) provisions or corporate structuring may give other covered investors access to those rights); this approach, however, may provide protection to a wide range of covered investors in excess of desired levels. It may also exacerbate the differential treatment of covered and non-covered investors.

51 As the Roundtable has noted in recent discussions, the duration of stand-alone investment treaties is typically lengthy, ranging from 10-20 years, and their impact is often further extended by survival clauses. See Kathryn Gordon \& Joachim Pohl, Investment Treaties over Time - Treaty Practice and Interpretation in a Changing World, OECD Working Papers on International Investment, 2015/02, pp. 20-22). FTAs typically provide for the possibility of unilateral exit often with relatively short notice, such as a year. However, the powerful economic integration generated by an FTA may make exit much more difficult than for a stand-alone investment treaty. As a result, in practice the investment provisions in an FTA may even be more long-term than typical bilateral investment treaties (BITs). 


\section{Impact of treaties on regulation}

The issue here is the impact of treaties on the functioning of government. It includes the power of governments to maintain, change, apply and enforce their policies.

\section{The impact of cases, damages liability and settlements}

At one level, the impact is clear. Governments have to defend cases, pay for the defence and fund any liability. Funds paid in damages are not available for other purposes. Cases and damages awards thus have an impact on government finances. The likelihood of cases as a respondent depends among other things on the amount of covered foreign investment stocks, the nature of applicable treaties, the quality of governance and settlement incentives.

Some governments appear to have under-estimated the risk of claims with the result that they have been surprised by their first cases and costs. ${ }^{52}$ Other governments have been subject to few claims to date. Estimating the degree of exposure to claims under potential treaties has become an important and contentious issue in the public debate, as exemplified by recent hearings held by the UK House of Lords on TTIP. In their oral testimony, experts such as Prof. Lauge Poulsen ${ }^{53}$ and former UK Attorney-General Lord Goldsmith ${ }^{54}$ expressed sharply different views about the likelihood of future claims:

Q212 Earl of Sandwich: We have heard in evidence that the UK for some reason does not get into so many disputes and that there are not so many settlements. Can you explain why that might be?

Dr Lauge Poulsen: Sure. The main reason is that the United Kingdom has traditionally not entered into investment treaties with major capital-exporting states, so when we think of the potential scenario that could result from the EU-US agreement, the more relevant set of experiences for the United Kingdom to consider is that of Canada. Canada entered into an investment treaty with the United States in the 1990s, which was Chapter 11 of the North American Free Trade Agreement. Following that agreement, the last time I checked Canada has been subject to 34 or 35 claims. About a handful of these claims have been lost and a couple of other claims have been settled. A couple of these settlements have been in favour of the investor, and I do not think there is any reason to expect the UK not to be subject to a similar number of claims as $8 \%$ of US outward foreign direct investment stock is in Canada while $13 \%$ is in the

$52 \quad$ Lauge N. Skovgaard Poulsen \& Emma Aisbett, When the claim hits: bilateral investment treaties and bounded rational learning (LSE Research Online: August 2012); see Kathryn Gordon \& Joachim Pohl, Investment Treaties over Time - Treaty Practice and Interpretation in a Changing World, OECD Working Papers on International Investment, 2015/02.

Lauge Poulsen was Research Fellow, Nuffield College, University of Oxford, and Senior Research Fellow at University of London, SOAS. He is currently Senior Lecturer in International Policy Economy at University College London.

Following his service as Attorney-General, Lord Goldsmith became a partner in a leading international arbitration law firm in 2007. He is also the Vice-Chairman of the Hong Kong International Arbitration Centre. 
United Kingdom. Bearing that statistic in mind we would expect more claims against the United Kingdom, all else being equal. All the top 100 of the top 500 companies in the United States operate in the United Kingdom in all sectors of the UK economy, ranging from services, manufacturing and finance to natural resources. And it is difficult to claim that the UK should somehow be exempt from claims by US investors when Canada was not.

Lord Goldsmith: I disagree with that very strongly. I think that is an odd way of looking at it. I think the reason why the UK is not subject to successful claims is the nature of the protections that exist already under UK law and practice. Claims can be brought only where there is, usually, an arbitrary or capricious action of the state in relation to an investment, and there is a range of reasons why that does not happen here. We have a strong democracy, and we have strong scrutiny by Parliament of measures such as expropriation. We have the Human Rights Act and the European Convention on Human Rights, which provide strong protection against those sorts of events. We also have a very objective, fair justice system that deals with claims where people have issues. So I would not expect there to be significant claims under ISDS. Claims may be brought against the UK - to date, there have only been two publicly known investor-state arbitrations involving the UK - and successful claims would be very limited. ${ }^{55}$

It appears that few governments have addressed how ISDS damages or settlement amounts will be funded. This may be in part because there is no domestic equivalent to ISDS damages liability: as the Roundtable has earlier noted, government liability for damages to investors under domestic law is generally limited to a narrow range of claims (expropriation and contract). ${ }^{56}$ There are few if any Trade and Investment Partnership, Written evidence volume, pp. 222-23 (question 212); see also The Transatlantic Trade and Investment Partnership (14th Report of Session 2013-14) § 161 (reporting on additional views about likely future exposure to claims). In its submissions to the Sub-Committee, the UK government noted that EU investors are also very active claimants. Id.

With regard to debates about the use of treaties by investors of different nationalities, it is worth recalling that, as the Roundtable has noted in the context of its work on shareholder claims, statistics on the national origin of ISDS claims often have little economic meaning. This is due to acceptance under many treaties of claims by intermediate holding companies that are indirect shareholders of an operating company, but have no economic activity in their "home" state. For example, while the Netherlands is one of the most-used home states for ISDS claimants, recent analysis by an NGO suggests that approximately $75 \%$ of claims under Dutch treaties are by intermediate holding companies owned by non-Dutch investors with no economic connection to the Netherlands. See Roeline Knottnerus et al, Socialising Losses, Privatising Gains (2015).

David Gaukrodger \& Kathryn Gordon, “Investor-State Dispute Settlement: A Scoping Paper for the Investment Policy Community", OECD Working Papers on International Investment, 2012/03, OECD Publishing, pp. 24-29, 79-87. 
examples of government liability to investors under domestic law for damages in the amounts at issue in ISDS. ${ }^{57}$

Settlements can also raise issues with regard to the impact on regulation. As some Roundtable participants have stated, negotiated primary remedies can be a valuable option, allowing the leverage provided by ISDS damages risk to provide the impetus for an agreed solution that takes the form of a primary non-pecuniary remedy, the same remedy that is available to domestic investors.

At the same time, there may be a perception that governments may have an interest in settling claims or potential claims quietly by acceding to foreign investor claims with regard to regulation rather than by paying damages or amounts in settlement (which may generate greater publicity or review). Lack of transparency in ISDS may feed concerns about impact on regulation. Concerns and benefits in this area may depend on, inter alia, general governmental transparency and scrutiny of the nature of agreed remedies.

Planning for future liability could mitigate the impact of ISDS on challenged regulation. Governments have been described by investors as facing major challenges in agreeing to monetary settlements due to the reluctance of officials to take responsibility for agreement to a voluntary payment. Robust systems to allow for settlement decisions involving money payments may make it easier for governments to settle for money damages rather than a regulatory change. Some jurisdictions have engaged in more thorough consideration of their future expected damages liability under ISDS, sometimes with a primary focus on attribution of liability between levels of government/administration. ${ }^{58}$

In addition to budgetary and regulatory impact of damages liability, defending claims can affect government regulatory policy on treaties themselves. Investment treaty policy changes can follow the first cases or awards against a government. In part, this may be due to the fact that they attract parliamentary attention and broader debate. Observed policy changes following claims include a reduction in the rate of negotiation of new treaties, renewed interest in developing or revising a model treaty, exit from treaties, clarifications to respond to arbitral decisions that are perceived to have overbroadly interpreted treaty provisions, and changes in treaty policy to address issues raised in cases.

The debate over broader "regulatory chill"

Beyond the effects on regulation of particular cases and damages awards, however, the debate over the impact of treaties is about their broader impact on government regulation and changes to regulation. The impact on the right to regulate in frequently addressed as an issue of whether treaties cause

$57 \quad$ Id.; see also Productivity Commission, Trade and Assistance Review 2013-2014 (2015), p. 78 ("While the amount of compensation sought by Philip Morris in its claim against the Australian Government has not been publicly disclosed, the company has stated it will be seeking substantial remedies and that financial losses that have resulted from the plain packaging laws. While the potential risk to future budget outcomes from this case was disclosed (for the first time) in the Australian Government's 2014-15 Budget Papers, the size of the risk has not been quantified nor provisioned in any substantive way.") The Australian government has indicated that cases will be funded, but that further information about these cases has not been disclosed on the grounds that it may prejudice the outcomes of these cases or may relate to commercial information. Id.

See Regulation (EU) No 912/2014 of the European Parliament and of the Council of 23 July 2014 establishing a framework for managing financial responsibility linked to investor-to-state dispute settlement tribunals established by international agreements to which the European Union is party. 
"regulatory chill". The term "regulatory chill", however, carries a pejorative connotation. While it is useful shorthand to refer to a particular debate, it will not be used for analytical purposes here. It is often recognised that it is valuable to "chill" or dissuade some types of regulation such as discriminatory regulation based on nationality; this lies behind the broad acceptance of national treatment obligations in investment and trade agreements.

For analytical purposes, it is useful to distinguish two issues: the question of the degree of impact of treaties on regulatory policy; and whether the impacts are good or bad from a policy perspective. This scoping paper addresses the first question. ${ }^{59}$

The degree of impact of treaties on regulatory policy may depend on several factors including the degree of awareness of treaties among relevant government actors, the dissuasive power of treaties and in particular of the applicable remedies, and the different types of treaty rules and standards.

a.

Awareness

In broad terms, government awareness can be of two types. First, there is the awareness of officials connected to a particular dispute or case. This arises at the latest as a result of investors threatening litigation in communications with relevant officials previously unaware of treaties or as a result of a claim being filed. It can also arise as a result of knowledgeable government officials becoming aware of the dispute. Post-dispute awareness can have effects on the regulation in dispute if, for example, officials modify it as part of a settlement. The issues raised in this context primarily relate to the impact on the challenged regulation itself as addressed above.

Second, there is the degree of general awareness of treaties across the broad public service that interacts with foreign investors. ${ }^{60}$ General awareness is necessary in order for treaties to have broad effects on regulatory action. ${ }^{61}$ Little is known about general awareness but indications suggest that it has traditionally been low. General awareness, including about treaty norms more specifically, can also be improved through government action, such as training programmes and referral mechanisms. Governments, however, have rarely sought to publicise treaties or the risk of liability.

$59 \quad$ The Roundtable has briefly considered the second question in its work on benefits and costs of treaties; governments have different views on the issue and no view is expressed in this paper. Further research, fact-finding and dialogue should allow a more thorough consideration as the work on the balance in treaties proceeds. Achieving a satisfactory balance may be a major contribution to maximising the net positive impacts.

See Jonathan Bonnitcha (2014), Substantive Protection under Investment Treaties: A Legal and Economic Analysis, p. 118 (distinguishing between "'threat' chill" and "'internalisation' chill" with the latter referring to general awareness).

The same differences between general awareness and post-dispute awareness exist with regard to investors. Covered investors naturally appreciate the additional leverage that treaties give them after a dispute arises. But only pre-dispute awareness is relevant to the degree of impact on investment decisions.

Lawyers serve as a key transmission belt for general awareness. There are now many articles outlining the special benefits provided by treaties for covered investors compared to investors limited to domestic law and domestic courts. Indeed, some of these extol the benefits of individual rules in specific types of treaties, contributing to investor awareness of specific rules. However, most lawyergenerated materials appear to be primarily directed at investors. Their impact on the awareness of government officials may be limited. 
General awareness can be greatly increased by high-profile cases, press coverage, and parliamentary and public debate. The on-going international and national debates about treaties and claims such as those relating to the regulation of cigarette marketing or nuclear power have likely had a significant impact on the awareness about treaties of many government officials.

Degrees of awareness vary. Officials may be vaguely aware of treaties, but have little or an inaccurate understanding of their operation or effects. While the growing public debate has undoubtedly improved awareness, misunderstandings about treaties still appear to be widespread. The uncertainty about the scope and interpretation of key treaty provisions makes it harder to improve understanding.

b. The dissuasive power of treaties on government action - the issue of remedies

A second question with regard to the impact of treaties on regulation is whether, assuming awareness among relevant officials of the potential for treaty claims, that awareness dissuades regulatory action.

The Roundtable has previously noted that final remedies in ISDS almost invariably take the form of damages. Some treaties in effect expressly limit final remedies to damages. This contrasts with advanced domestic systems of administrative law which generally provide only for non-pecuniary or primary remedies for investors in judicial-review type proceedings (except for expropriation or contract). ${ }^{62}$

Damages in ISDS can be huge with awards running into the billions of dollars. Claimants routinely seek lost profits over the course of a project. Awarded damages are generally a small fraction of the claimed amounts, but still dwarf any known examples of government damages liability under domestic law.

In some contexts, it has been suggested in general terms that damages remedies do not affect regulatory autonomy because the government can still regulate providing it pays for the associated costs. If accepted in full, this view would suggest that the right to regulate issue could be eliminated by the simple expedient of limiting remedies to damages. Some broad and unqualified statements by governments that treaties do not affect the right to regulate because arbitrators cannot override policy decisions may be based on this unstated premise.

One issue with regard to this premise is that damages are generally recognised to be a powerful dissuasive tool. Many regulatory and legal regimes rely on the power of damages liability to affect corporate behaviour. Regimes for fines in competition policy or corporate liability for bribery are remedies designed to dissuade certain behaviour. Tort liability for damages often has a similar dissuasive purpose.

In the specific field of government liability for damages, a UK Law Commission report outlined the concerns -- frequently expressed by courts -- that government damages liability for regulatory action would dissuade regulatory action. As was noted in the ISDS Scoping Paper, the UK courts "frequently

62 David Gaukrodger \& Kathryn Gordon, “Investor-State Dispute Settlement: A Scoping Paper for the Investment Policy Community”, OECD Working Papers on International Investment, 2012/03, pp. 7988. As noted in earlier Roundtable work, the non-pecuniary remedies available under domestic law are often available in streamlined proceedings. The accelerated nature of WTO proceedings responds to the same imperative in a system in which damages are unavailable. See Peter van den Bossche, The Law and Policy of the World Trade Organisation, (2d ed. 2007) p. 200 (rapid decisions are important because there are no damages). 
refer to a number of policy arguments against state tort liability in damages. Potential liability is seen as likely to harm the quality of administration by (i) leading public bodies and their employees to take an unduly defensive approach to their work; (ii) diverting scarce resources away from the primary functions of public bodies and towards efforts to avoid litigation and defensive measures; and (iii) potentially leading to a great number of lawsuits and vexatious claims, further reducing the available resources for public bodies." ${ }^{63}$ These reasons, along with the general concern about government budgets in domestic courts, are among the principal justifications for the use of primary remedies rather than damages as the remedies in domestic administrative law.

Moreover, it seems clear that, as a matter of good policy, governments should consider possible damages liability as part of their cost-benefit analysis of potential regulation. Good regulatory policies, including as recommended by the OECD, include the careful weighing of the costs, benefits and risks of proposed regulation. Government administrative costs are a core component of cost-benefit analysis. ${ }^{64}$ Expected litigation costs and possible government liability including for future lost profits of affected regulated entities are undoubtedly important costs to be considered in this context. ${ }^{65}$ Thus, potential damages liability should dissuade regulatory action that generates risks of government damages liability.

The incentives of governments and government officials are generally considered to be more complex in this regard than those of a profit-maximizing entity like a business. Nonetheless, cost-benefit analysis generally assumes that officials can usefully integrate financial costs as a factor in their decision-making. Potential treaty liability can in theory further reinforce officials' interest in considering the private costs of regulation.

While the OECD thus recommends that known potential damages liability should be factored into the consideration of regulatory policy, whether this is done in fact is an empirical question. There is limited evidence on this question. Studies on regulatory chill cites some examples where government action appears to have been chilled, and others where governments have proceeded with regulatory action notwithstanding the threat of litigation or an actual claim. Further research and input are required. It is noteworthy that one well-known arbitration practitioner as arbitrator and counsel has seen the issue arise in his practice, but finds it difficult to offer reassuring advice to governments due to the nature of ISDS:

David Gaukrodger \& Kathryn Gordon, “Investor-State Dispute Settlement: A Scoping Paper for the Investment Policy Community”, OECD Working Papers on International Investment, 2012/03, pp. 81 82 (citing Law Commission, Administrative Redress: Public Bodies and the Citizen: A Consultation Paper (2008) $\S \S 3.129,3.139-3.153)$.

See OECD, Recommendation of the Council on Regulatory Policy and Governance 4.4 ("When regulatory proposals would have significant impacts, ex ante assessment of costs, benefits and risks should be quantitative whenever possible. Regulatory costs include direct costs (administrative, financial and capital costs) as well as indirect costs (opportunity costs) whether borne by businesses, citizens or government."); See, e.g., White House, US, Regulatory Impact Analysis: A Primer; Canadian Cost-Benefit Analysis Guide: Regulatory Proposals, $§ 4.3$ (2007) (administrative costs incurred by government are direct costs that should be considered).

Governments with advanced administrative law systems may need to take action to educate officials about the new litigation and damages liability exposure. As noted, domestic law rarely grants damages to investors except for cases of expropriation or contract. Domestic administrative costs arising from challenges to regulation are mainly related to the limited legal costs of judicial review type proceedings. 
'Without doubt, "regulatory chill", in my view, definitely exists, and there's palpable evidence of it,' [Toby Landau] says. 'There are those who deny it, but I can say that in my role as counsel, on a number of occasions now I've actually been instructed by governments to advise on possible adverse implications or consequences of a particular policy in terms of investor-state (ISDS) cases.'

Landau says it's very difficult for him to give definitive advice to governments on ISDS cases, because the international tribunals they're adjudicated in behave very differently to regular courts.

'It's an area where there is no system of precedent, where the rules are very vaguely, broadly drafted, where there have been many inconsistent decisions already on the same issue, and it depends on who the arbitrators (judges) are,' he says.

'As a result, the chill effect, in my view, is much broader than other areas of law because a government that wants to be careful and prudent, and avoid any risk of an investor-state case, is likely to shift away from a particular policy if there's any risk of a claim. And the advice it's likely to get is, "One cannot discount the risk."166

While this is only one view, the perspective of a lawyer faced with providing legal advice to governments about their exposure under ISDS merits attention.

c. Types of rules

The impact of different types of legal rules as incentives or disincentives for behaviour -- in this case on government behaviour - is a major field of inquiry in itself. For present purposes, the issues in this area are merely sampled in relation to two different questions of central interest: (i) the issue of uncertainty -- the costs of uncertain rules in dissuading permissible measures; and (ii) a few preliminary considerations about the question of legitimate expectations.

Clear rules may reduce dissuasion of permissible measures. Roundtable participants have expressed serious concerns about the issue of inconsistency in the context of discussions of ISDS. ${ }^{67}$ The issue is relevant to among other things the impact of treaties on regulatory action. Broad and vague rules mean that regulators will likely perceive a risk for a broader range of measures, in effect expanding the scope of impact of treaties:

Investment treaty protections that give arbitrators unstructured discretions or that turn on ex post judgment that decision-makers cannot easily predict when considering the adoption of measures prospectively are likely to be associated with greater uncertainty and greater chilling of measures that would have been permissible. ${ }^{68}$ Australian Broadcasting Corporation, Background briefing, ISDS: The devil in the trade deal (26 July 2015) (transcript of 14 September 2014 broadcast).

OECD, Government perspectives on investor-state dispute settlement: a progress report (14 December 2012), pp. 17-18.

Jonathan Bonnitcha (2014), Substantive Protection under Investment Treaties: A Legal and Economic Analysis, p. 127. 
Uncertainty about the legal rules can also make it difficult to operate internal referral programmes to advise officials meaningfully on obligations and risks as they consider policy options.

Legitimate expectations. The question of whether and how treaties protect covered investors' legitimate expectations is an important element in many debates about the balance of the right to regulate and investor protection. ${ }^{69}$ It is a question for additional research and fact-finding, but given its centrality, some basic considerations are set forth in this scoping paper.

It does not appear that the text of any currently-applicable investment treaty refers to legitimate expectations although more research is necessary. Investment tribunals have taken different approaches to legitimate expectations. Under treaties that merely refer to FET without further clarification, ISDS arbitrators have frequently applied various versions of a doctrine of legitimate expectations to find governments liable for treaty breaches of the FET clause. As noted in the Introduction, this has been a recent development. In contrast, no NAFTA tribunal had based liability under FET on a theory of legitimate expectations until a decision rendered in 2015. NAFTA contains a version of FET that is limited to the minimum standard of treatment (MST) under customary international law. ${ }^{70}$

Notwithstanding its absence from the text of treaties, the doctrine of legitimate expectations is one of the alleged rules most frequently invoked by investor claimants. As applied in different arbitral decisions, the content of the legitimate expectations rule as an element of FET varies significantly. At its broadest, the doctrine has been considered to permit covered foreign investors to recover increased costs incurred as a result of substantial changes in a regulatory framework on which they have relied. ${ }^{71}$ This version of the rule would appear to be likely to significantly affect regulatory autonomy by raising the governmental costs of regulatory change including for non-discriminatory measures.

A second version of the legitimate expectations rule as applied in some ISDS cases can protect covered investors from the costs of regulatory change where they have relied on "specific commitments" from governments or government officials. This doctrine can in effect give contractual

See, e.g., Rudolf Dolzer (2013), Fair and Equitable Treatment: Today's Contours, 12 Santa Clara Journal of International Law, 7 (2013), p. 17 ("The rationale and justification for the recognition of legitimate expectations seems obvious. The investor makes its calculations and decisions in the light of the law of the host state as it is made available to it by the host state, and the investor's assumptions about the return for its investment will depend upon the stability and predictability of those laws. Had the legal order been different, this decision to invest might have been different".); see Christopher Campbell, House of Cards: The Relevance of Legitimate Expectations under Fair and Equitable Treatment Provisions in Investment Treaty Law, Journal of International Arbitration, Kluwer Law International 2013, Vol. 30, Issue 4, p. 361 ("When state regulatory conduct changes contrary to the legitimate expectations of the investor, negatively affecting the investment, this may breach FET provisions. This concept is not referred to in any [investment treaty] provisions; it is essentially an arbitral innovation. This test risks giving too much weight to the investor's interests at the expense of public interests and a state's right to regulate legitimately. Furthermore, if applying such a notion, extreme care must be given to the level of development of the host state in determining what expectations may in fact be 'legitimate."').

As noted, this approach is explored in a companion paper. See David Gaukrodger, Addressing the Balance of Interests in Investment Treaties, OECD Working Papers on International Investment $2017 / 3$.

See Tecmed v. Mexico, ICSID Case No ARB (AF)/00/2, Award, 29 May 2003; CMS v. Argentina, ICSID Case No. ARB/01/8, Award, 12 May 2005. 
force to "specific commitments" in contexts where the normal requirements for formation of a contract may not be satisfied. Much of course depends on how the notion of specific commitments is defined (and how it relates to the rules for formation of contract under domestic law). However, like legitimate expectations generally, it is rarely mentioned or defined in treaty text. ${ }^{72}$

By providing a possible basis for liability for non-discriminatory measures based on a potentially broad range of prior statements, actions, representations or promises, the specific commitments doctrine would also appear to have significant potential to affect regulatory autonomy. It provides covered investors with correspondingly greater protection. The doctrine may make government advice to regulated entities more risky and therefore affect the supply of such information over time. Conversely, it increases the incentive for prospective covered investors to seek informal commitments about regulatory policy before investing on which they may seek to rely in the future.

National law appears to take different approaches to the question of legitimate expectations as a doctrinal matter although further research is required. However, there appears to be considerable consistency in terms of concrete outcomes: the ISDS Scoping Paper found no examples of large damages awards to investors under national law (except for expropriation and contract), whether under theories of legitimate expectations or otherwise. ${ }^{73}$ This finding should be further explored and updated.

\section{Balancing}

Views differ about the appropriate balance among governments and others. For illustrative purposes, the preliminary discussion here will introduce some developments and themes that Roundtable participants may wish to consider as they engage in analysis and discussion of balancing. Further analysis will be informed by additional research and fact-finding.

1. Economic analysis of investment treaty rules can provide useful theoretical insights and generate empirical questions for testing

The recent academic attention to intensive economic analysis of investment treaty rules is an important development. Until recently, attention was primarily focused on the question of the impact of treaties on FDI, but little attention to other policy issues. The new approaches frequently build on similar analysis in national jurisdictions. In some national jurisdictions, rules or proposed rules providing certain forms of investor protection analogous to investment treaty rules have been the subject of debate, proposed amendments and extensive law and economics analysis.

An important example relates to the economic analysis of what has been termed "transition policy". Transition policy analysis is an important reference because investment treaty claims have been focused to a considerable degree on issues raised by changes to government policy. Many investors have claimed treaty protection for changes to regulation following their investment.

72

See 2016 CETA, art. 8.10(4): Treatment of Investors and of Covered Investments: "When applying the above fair and equitable treatment obligation, a tribunal may take into account whether a Party made a specific representation to an investor to induce a covered investment, that created a legitimate expectation, and upon which the investor relied in deciding to make or maintain the covered investment, but that the Party subsequently frustrated."

David Gaukrodger \& Kathryn Gordon, “Investor-State Dispute Settlement: A Scoping Paper for the Investment Policy Community", OECD Working Papers on International Investment, 2012/03, OECD Publishing, pp. 24-29; OECD (2012), Government perspectives on investor-state dispute settlement: a progress report, Freedom of Investment Roundtable, 14 December 2012, pp. 9-10. 
Transition policy considers how best to address legal transitions -- changes in government policy. It recognises that practically all changes in government policy impose gains and losses on those who, prior to the change, had taken actions with long-term consequences. It addresses whether and how the impacts of policy change upon pre-existing investments should be compensated or otherwise mitigated.

Transition policy has been the subject to extensive economic and institutional analysis. In a wellknown 1986 article, Louis Kaplow considered, for example, the policy basis for protection of legitimate expectations in that context. ${ }^{74}$ The analysis evaluates the impact of different types of transition policies both on investors and on government as an institution.

The recent economic analysis of treaty rules has built on the economic analysis by Kaplow and others. However, it also seeks to take account of the specific characteristics of investment treaties including their application limited to covered foreign investors. ${ }^{75}$ This type of analysis can generate hypotheses about expected effects. It can also generate empirical questions for which evidence can be gathered. It is an important source for work on the balance between the right to regulate and investor protection.

\section{Careful analysis of rules may allow for a reduced need for balancing of policy goals}

The balancing question is often conceived of as one of balancing economic and non-economic objectives. As framed in the debate over the balance between investor protection and the right to regulate, the primary competing goals are often seen to be the preservation of governments' ability to regulate and achieve policy goals in key areas such the environment, and the desire to achieve improved economic efficiency through better-protected and therefore increased FDI. Investor protections are seen as achieving economic objectives (efficiency and the attraction of FDI); the right to regulate is seen as important to allow the achievement of non-economic objectives, such as environmental protection.

These competing goals are often seen as in conflict, which makes balancing difficult. However, Jonathan Bonnitcha has suggested that economic analysis may reveal that there may be less need for balancing than is often thought:

"[E]conomic" objectives of investment treaties -- efficiency and the
attraction of FDI -- are not necessarily in tension with "non-
economic" objectives ... This is because the economic justifications
for investment treaties are weaker than is generally supposed.
Protections that are more favourable to the interests of foreign
investors are not, self-evidently, associated with net economic
benefits.

The law and economics analysis that leads to this view is detailed. It is beyond the scope of this scoping paper and no view is expressed about its accuracy. It is important to also consider, for example, the proposition that protection for covered foreign investors can contribute to non-economic

\footnotetext{
74 See Louis Kaplow, An Economic Analysis of Legal Transitions, 99 Harvard Law Review 509 (1986).

See, e.g., Jonathan Bonnitcha (2014), Substantive Protection under Investment Treaties: A Legal and Economic Analysis; E. Aisbett, Police Powers, Regulatory takings and the Efficient compensation of domestic and foreign investors, (2010) 86 The Economic Record 367. Analysis, p. 13.
} 
goals by fostering FDI that has a smaller environmental footprint. Non-economic objectives for investment treaty protection for foreign investors also need to be considered.

The broader point for present purposes is that careful analysis and tailoring of rules may contribute to reduce the need for balancing. Reduced tension between differing objectives could help increase public support for treaty policy.

3. Governments can use a wide variety of techniques to adjust the balance in future treaties and related law, but addressing the many existing treaties is difficult

Analysis of the debate on the balance of investor protection and the right to regulate should take account of the broad range of techniques that governments can use to affect the balance. The most obvious technique involves decisions about whether to include or exclude particular provisions, whether to draft them narrowly or broadly, precisely or in vague terms. The most important provisions in this regard are likely to be those most often at issue in investor claims. A second area of obvious interest are express provisions addressing the right to regulate. Some have pointed to risks that broad clauses to protect the right to regulate could create new areas of possible misinterpretation.

A partial list of additional techniques used recently to re-balance treaties to allow for greater policy space would likely include the following: clarifications of treaty language; interpretative statements; joint interpretive statements; general exceptions; specific exceptions; reservations; conditions precedent to consent to arbitration; standards of review; limits or exclusions of MFN clauses; or limits on injunctions, damages or other remedies. ${ }^{77}$ There appear to have been fewer recent treaty modifications to expand investor protection, but a significant list could likely also be identified. ${ }^{78}$

Beyond treaties and ISDS, there are many other types of government action that can affect the balance. These include policies on defending cases, intervening as a non-disputing party, following treaty developments and making statements about relevant treaty interpretations issues. Other types of relevant government action include diplomatic action in fora addressing treaties such as the Roundtable or UNCTAD.

Improvements to new treaties are valuable, but leave the issue of existing treaties unaddressed. ${ }^{79}$ Many Roundtable and other governments have large networks of existing treaties. Renegotiation is timeconsuming and expensive particularly now that treaties are more often the subject of significant negotiations. If analysis of treaty policy leads to growing convergence of views about valuable approaches, joint action by governments could assist in updating and modernising the many existing treaties.

77 Catharine Titi, for example, who defines the right to regulate narrowly as specific exceptions to investment protection provisions. See Catharine Titi (2014), The Right to Regulate in International Investment Law.

78 Changes to the ISDS system can also be relevant to the balance, but as noted above the initial analysis here excludes the ISDS system.

Indeed, some improvements may cause more problems than they resolve. A new formulation of a provision in a new treaty may give rise to the negative inference that earlier treaties with different language must have a different meaning. Where the improvement is designed to respond to unwelcome arbitral interpretations and reaffirm the original intent in clearer terms, some governments use agreed clarifications of the language used in earlier treaties rather than different treaty text. This avoids the negative inference. 
a. Balancing of policy goals is difficult and controversial, and raises issues of legitimacy

Balancing of policy goals is carried out by different actors and in different contexts. National governments and in particular their legislatures routinely engage in the balancing of interests in adopting policy. Elected officials and bodies are often seen as having particular legitimacy to engage in balancing.

With regard to the balance in investment treaties, governments can engage in balancing in their treaty drafting (and actions relating to other applicable law such as customary international law). The development of model treaties in recent years has given rise to intensive debates about the appropriate balance between policy goals. The balancing can involve intensive input from stakeholders; increased public awareness of treaties can expand the range of active stakeholders. The balancing process continues in the context of negotiations with other governments. It is also at issue in the preparation of government submissions in cases either as a disputing or non-disputing party. It has been suggested that development of a model, while challenging, can help address concerns about one government binding a future government to policy constraints. ${ }^{80}$

For governments, there are issues about the respective roles of the executive and legislative branches in the balancing process in investment treaties, and of different levels of government in federal-type systems. Generally, within governments, it appears that treaty policy has been primarily defined by the executive branch in most countries. As public interest in treaties and concerns about the impact of treaties on the right to regulate have grown, parliaments have become more active in some jurisdictions in seeking to influence the balance that is struck. Commentators have recently suggested that the public debate over ISDS in Australia has contributed to the Senate's Foreign Affairs and Trade References Committee commencing a broad inquiry into the constitutional allocation of treaty-making authority. ${ }^{81}$

In some countries, like the United States, Congress has defined specific negotiating parameters for US trade and investment agreements. These have included important principles relating to the balance of

80 Recent parliamentary hearings in Australia have addressed this question:

CHAIR (Senator Alex Gallacher): Given that treaties are binding on governments that may win elections later on, it would be a sign, if you like, that a model agreement thrashed out properly would be in Australia's best interest ...

Prof. [Luke] Nottage : I think so. In fact that is the experience in other countries that have embarked on this sort of process. I mentioned just now that one outcome of this might be a model treaty that lists certain types of options as a compromise, particularly on contentious points at issue. When you look at the model BITs, they do not give those options. They tend to manage to reach agreement on particular provisions. That is not to say that future iterations of these in those other countries or in our country, if we go down this road, will necessarily be able to reach full agreement in terms of a model. But I think there is certainly great scope to bring more understanding and therefore common ground in terms of the sorts of provisions that we can have - that can survive changes of government at the national level.

Parliament of Australia, Senate, Foreign Affairs, Defence and Trade References Committee, Hearings on the Commonwealth's Treaty-Making Process (5 May 2015), p. 65.

$81 \quad$ Jurgen Kurtz \& Luke Nottage, Investment Treaty Arbitration 'Down Under': Policy and Politics in Australia, ICSID Review, (2015) 1 at p. 15 (citing Parliament of Australia, 'The Commonwealth's Treaty-Making Process'.) 
investor protection and the right to regulate, such as a requirement that US treaties not give foreign investors greater substantive rights than US investors under US law. They can be associated with agreement to "fast-track" treatment of the ratification process for signed agreements under certain conditions. The no greater substantive rights principle has been an important guidepost in the development of US Model BITs since 2002.

The situation in the European Union is more complex and is not yet fully clarified in the wake of the Lisbon Treaty modifications to the EU treaties. The Council defines negotiating mandates and the Commission conducts the negotiations. But both the European Parliament and EU member state parliaments have become active participants in defining EU treaty policy, including in some cases the balance.

In some common law systems, the need for parliamentary attention to treaties can depend on whether the treaty requires changes in legislation. Although they create substantial contingent liabilities, investment treaties generally do not require any immediate legislative changes. Consequently, the role for parliaments in their adoption and ratification, as least as a formal matter, is often quite limited in these systems.

As noted, treaties are negotiated with other parties and the balancing process continues in that context. Growing awareness of the importance of the trade-offs at issue has led to pressure for greater transparency of trade and investment negotiations in many jurisdictions. A number of governments have sought to increase transparency while preserving their capacity to negotiate effectively.

b. What role should adjudicators have, if any, in balancing policy goals?

Courts generally lack the democratic legitimacy of parliaments. Consequently, their role in balancing policy goals, if any, is often perceived as controversial. Review of legislation in particular is often reserved to special constitutional courts and limited to review of constitutionality. However, different national and regional traditions may have different views about the balancing of policy goals by courts.

ISDS cases frequently involve review of decisions by a primary administrative decision-maker under national law. Such decision-makers may be charged with balancing policy goals.

Under domestic law in many countries and some systems of international law, standards of review help define the respective roles of primary decision-makers and of adjudicators reviewing their actions in balancing policy goals. Standards of review determine the degree of scrutiny that courts or tribunals will apply to government conduct.

Standards of review can be strict (interventionist) or deferential. A strict or interventionist approach involves the adjudicator largely substituting itself for the primary decision-maker. The adjudicator engages in full "de novo" review of the relevant measure and its rationale. The underlying decision must correctly apply the law as seen by the adjudicator. The adjudicator can thoroughly review the factual record rather than deferring to findings of fact by the primary decision-maker. It may also create an entirely new factual record.

A deferential approach involves an adjudicator exercising restraint. The adjudicator may defer to the decision of the primary decision even where the adjudicator would have or might have decided the issue differently if it had been the primary decision-maker. It can defer to findings of fact or law or both. 
Some domestic systems recognise different levels of scrutiny with the appropriate level depending on various factors. Factors can include the nature of the rights at issue, the purpose of the government measure and the relative expertise of the governmental decision-makers and the reviewing adjudicating body ${ }^{82}$ Economic or social legislation is often reviewed less strictly than legislation that affects fundamental rights.

The varying degrees of scrutiny by adjudicators of the action of primary decision-makers can thus apply to a range of issues, including legal interpretations, factual determinations and substantive policy choices.

In international law, both the European Court of Human Rights and the WTO system have developed standards of review. The ECHR uses a margin of appreciation doctrine. Anthea Roberts describes the doctrine as embodying two principles that provide a degree of deference:

This doctrine embodies two principles: judicial deference, meaning that international tribunals should exercise a certain degree of judicial restraint when evaluating the actions of national authorities, giving some deference to their decisions rather than undertaking full, de novo evaluations; and normative flexibility, meaning that some international norms are sufficiently open-ended or uncertain that they can be met in a variety of ways, giving States a certain "zone of legality" in which they are free to act. ${ }^{83}$

The WTO does not contain an express provision on the standard of review. However, the Appellate Body has established some guidance for the degree of deference that WTO panels should apply to the review of government action. ${ }^{84}$

While courts and tribunals have often developed standards of review of government action through their cases, standards can be included in laws or treaties. There appear to have been few if any references to standards of review in investment treaties to date. One notable exception is the provisions on financial services in CETA as seen above which expressly establish a highly deferential and detailed standard of review.

Several commentators have criticised ISDS for failing to develop standards of review that would, it is contended, assist in balancing policy goals. As noted by Anthea Roberts, " we are witnessing growing calls by States, academics and NGOs for investment arbitral tribunals to recognize that they are engaged in a form of international judicial review and thus should adopt appropriate levels of deference when reviewing the legislative, executive and judicial acts of respondent States". ${ }^{85}$

As noted, standards of review are often based on, among other things, the relative institutional strengths and weaknesses of both the primary decision-maker and the reviewing adjudicator. Ad hoc arbitrators can add further issues with regard to legitimacy and institutional competence beyond those applicable to courts. For example, depending on selection processes, issues may arise about whether

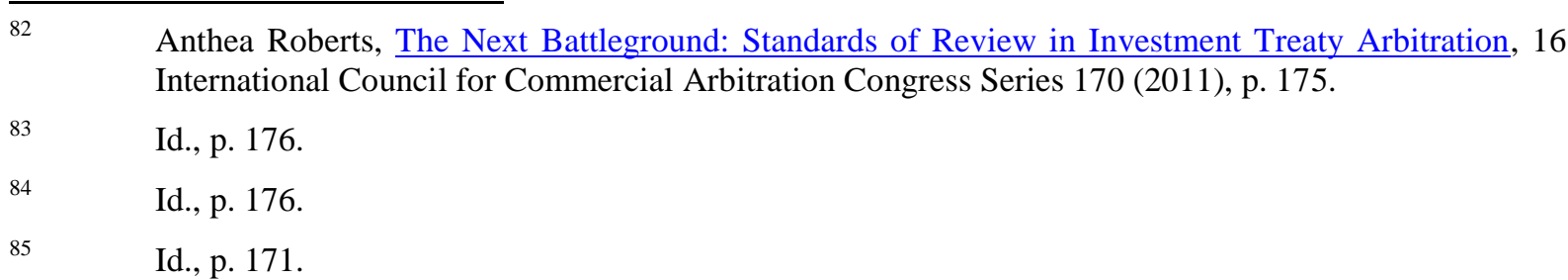


the pool of arbitrators has the requisite neutrality vis a vis the competing policy goals. Some suggest that institutional weaknesses of ISDS should prompt ISDS tribunals to give national governments a high level of deference. Other argue that ISDS tribunals are superior to national courts especially for claims against governments because the latter suffer from national bias.

There have been many proposed approaches to the question of standards of review in investment arbitration. They include the margin of appreciation, proportionality, rational basis and others. They vary in their degree of strictness or deference to the primary decision-maker. They therefore can affect not only the relative interpretive power of tribunals and governments, but also the balance of the right to regulate and investor protection. Further research is needed in this area.

\section{Conclusion}

This scoping paper outlines issues raised by the balance between investor protection and the right to regulate in investment treaties. A wide range of issues in this area may merit attention from the FOI Roundtable and others. As noted, a companion paper starts the fact-finding process on these issues by beginning to examine government action to address the balance. 


\section{ANNEX 1: EMPIRICAL AND POLICY ISSUES}

- Has your government considered the balance between investor protection and the right to regulate in investment treaties in the light of similar issues in other contexts such as the WTO and the GATS? What similarities and differences do you see?

- Do challenges to legislation adopted by parliaments raise different issues than challenges to regulation? On what basis? Are there grounds in current treaties to distinguish between different types of domestic law?

- What are your views on challenges to the decisions of supreme courts?

- Is the process of domestic law review of government decisions, including appeals, a valuable component of the quality of regulation? Does the direct availability of ISDS review for administrative measures (without passing through the domestic courts) have an effect on regulation?

- Is there a trend towards greater specific regulation by sector including modified approaches to ISDS? If so, what are the explanations for the growth of more protective regimes?

- If special protections or amendment systems are needed to protect the right to regulate in certain sectors, are questions likely to arise about why they not appropriate for regulation in other sectors? Are they likely to be seen as reflecting a hierarchy of governmental regulatory interests?

- In your view, do different types of rules in treaties have a different impact on the right to regulate?

- A number of Roundtable participants pointed to the ongoing debate in their jurisdictions as part of the rationale to examine the balance. For participants with an active debate, do you consider that redefinition or elimination of certain rules could change the quality of debate in your country and increase public support, or are the concerns more diffuse and unconnected with specific rules?

- Has your government analysed its contingent liabilities under ISDS, as suggested by the Australian Productivity Commission as part of cost/benefit analysis? How are damages amounts expected to be funded? Would they be likely to affect regulatory policy? 
- Settlement of a case with a cash payment requires an administrative or political decision to incur, by consent, a financial cost. Has your government examined how funds would be made available for settlement of ISDS cases? Would you expect that it would be difficult for officials in your government to agree to a settlement for a substantial amount of damages? Has your government settled multi-million dollar cases under your domestic law? Would institutional reforms improve settlement capacity?

- Efforts to increase the impact of treaties through improved government awareness about treaty provisions would likely need to draw attention to key differences between domestic law principles and ISDS, such as covered investors' typical right to sidestep national courts and proceed directly to seek damages in ISDS. It would also need to identify differences between treaty rules and domestic law rules with which officials may be familiar. Are efforts of this nature likely also to contribute to debate about the impact of treaties on a level playing field and fairness to domestic investors?

- Has your government attempted to create guidelines to explain particular investment treaty rules to government officials? Can guidelines effectively capture rules applied in ISDS?

- Has the awareness of your Parliament about treaties increased in recent years? Has your government taken measures to improve parliamentary understanding of treaties and the issue of balance?

- What are your views on the relative dissuasive impact of damages and primary remedies on governments and government officials?

- Has your government sought legal advice about its exposure to ISDS damages claims with regard to proposed new measures? From in-house counsel? From outside counsel? If so, how do you identify measures that require such review?

- Is it persuasive to suggest that treaties that limit remedies to damages have no or limited impact on the right to regulate? Why or why not?

- Are the policy considerations identified in case law by the UK Law Commission with regard to the impact of government damages liability on regulatory action relevant to investment treaty policy? Are national judges too protective of the public purse?

- What are your views on the impact of uncertain legal rules on regulatory policy and decision-making?

- Does your national law protect legitimate expectations with a damages remedy? What are your views on the impact of protection of legitimate expectations on the right to regulate? 
- What parts of your government participate in developing treaty policy and balancing between investor protection and the right to regulate?

- Has your parliament become more active on issues of treaty policy in recent years? Has this affected the process of deciding on the balance between investor protection and the right to regulate?

- Does your government have a model treaty? How has the process of reaching a balance between investor protection and the right to regulate been achieved in the model?

- A number of models developed recently appear to have resulted from both more intensive analysis and higher-level government attention to the trade-offs and balancing at issue than earlier models. In your view, is this likely to affect negotiations about the balance with other governments?

- Does the limited transparency of major treaty negotiations contribute to a focus of public debate on ISDS rather than on treaty content (which remains unknown)?

- The Roundtable has noted most commentary on ISDS analyses arbitral interpretations of treaties. Under these conditions, most commentary has focused more on the arbitral role in balancing rather than on balancing by governments. As government attention to treaty practice becomes more intensive, should governments' role in balancing be emphasised? How could this be achieved? Would this have an impact on the debate over ISDS?

- How important are the rules compared to the arbitrators in determining the impact of treaties on the right to regulate? Where should governments concerned about that impact concentrate their energies? 


\title{
OECD Working Papers on International Investment
}

\author{
www.oecd.org/investment/working-papers.htm
}

2017

$2017 / 1$

2016

$2016 / 3$

$2016 / 2$

$2016 / 1$

2015

$2015 / 3$

$2015 / 2$

$2015 / 1$

2014

$2014 / 3$

$2014 / 2$

2013

2013/4

2013/3

2013/2

2013/1

2012

2012/3

2012/2

2012/1

2011

$2011 / 2$

2011/1

2010

2010/3

2010/2

2010/1

2006

2006/4

2006/3

$2006 / 2$

2006/1

Foreign direct investment, corruption and the OECD Anti-Bribery Convention

State-to-State dispute settlement and the interpretation of investment treaties

Investment policies related to national security

The legal framework applicable to joint interpretive agreements of investment treaties

Currency-based measures targeting banks - Balancing national regulation of risk and financial openness

Investment Treaties over Time - Treaty Practice and Interpretation in a Changing World

The Policy Landscape for International Investment by Government-controlled Investors: A Fact Finding Survey

Investment Treaties and Shareholder Claims: Analysis of Treaty Practice

Investment Treaties and Shareholder Claims for Reflective Loss: Insights from Advanced Systems of Corporate Law

Investment Treaty Law, Sustainable Development and Responsible Business Conduct: A Fact Finding Survey

Temporal validity of international investment agreements: a large sample survey of treaty provisions Investment treaties as corporate law: Shareholder claims and issues of consistency

Lessons from Investment Policy Reform in Korea

China Investment Policy: an Update

Investor-state dispute settlement: A scoping paper for the investment policy community

Dispute settlement provisions in international investment agreements: A large sample survey

Corporate greenhouse gas emission reporting: A stocktaking of government schemes

Defining and measuring green FDI: An exploratory review of existing work and evidence

Environmental concerns in international investment agreements: a survey

OECD's FDI Restrictiveness Index: 2010 Update

Foreign state immunity and foreign government controlled investors

Intellectual property rights in international investment agreements

OECD's FDI regulatory restrictiveness index: Revision and extension to more economies

Interpretation of the Umbrella Clause in Investment Agreements

Investor-State Dispute Settlement in Infrastructure Projects

Improving the System of Investor-State Dispute Settlement: An Overview 
2005/3 Corporate Responsibility Practices of Emerging Market Companies - A Fact-Finding Study

2005/2 Multilateral Influences on the OECD Guidelines for Multinational Enterprises

2005/1 Transparency and Third Party Participation in Investor-State Dispute Settlement Procedures

\section{4}

2004/6

\section{9}

1999/3 Rules for the Global Economy: Synergies between Voluntary and Binding Approaches

$1999 / 2$

$1999 / 1$

Mobilising Investment for Development: Role of ODA - The 1993-2003 Experience in Vietnam

ODA and Investment for Development: What Guidance can be drawn from Investment Climate Scoreboards? Indirect Expropriation and the Right to Regulate in International Investment Law

Fair and Equitable Treatment Standard in International Investment Law

Most-Favoured-Nation Treatment in International Investment Law

Relationships between International Investment Agreements

\section{Business Approaches to Combating Corrupt Practices}

Incentives-based Competition for Foreign Direct Investment: The Case of Brazil

Managing Working Conditions in the Supply Chain: A Fact-Finding Study of Corporate Practices

Multinational Enterprises in Situations of Violent Conflict and Widespread Human Rights Abuses

Codes of Corporate Conduct: Expanded review of their contents

The OECD Guidelines for Multinational Enterprises and other corporate responsibility instruments Public policy and voluntary initiatives: What roles have governments played?

Making codes of corporate conduct work: Management control systems and corporate responsibility

Corporate Responsibility: Results of a fact-finding mission on private initiatives

Private Initiatives for Corporate Responsibility: An Analysis

Recent trends, policies and challenges in South East European countries

Main determinants and impacts of FDI on China's economy

Lithuania: Foreign Direct Investment Impact and Policy Analysis

Investment Patterns in a Longer-Term Perspective

Bribery and the business sector: Managing the relationship

\section{8}

